\title{
Fruits Related Problems and Their Management in Rajouri District of Jammu and Kashmir
}

\author{
Dr. Nawaz Ahmed and Prof. Taseem Ahmed
}

\begin{abstract}
Fruit trees in Rajouri district of Jammu and Kashmir like other plantations in different parts of the state, nation and world are facing host of problems and inadequacies such as undulating topography, varying climatic and soil conditions, scanty cultivable land, and serious soil erosion. On the other hand they are exposed to the ravages of pests and diseases. With the intensification of agricultural production practices and evolution of high yielding varieties and types of various fruit crops, the resurgence of the pests has out broken massively. Besides pests of known identity some new races of flies, beetles, and caterpillars are becoming new menace. They rob a measurable and considerable portion of the farmer's profit. As per estimate about 20 percent of the total loss to the crops is attributed to the insect's pests alone. Therefore proper management of the pest is crucial to harvest good crop.
\end{abstract}

\section{Introduction}

The pests and diseases of fruit plants not only reduce the productive capability of trees but also affect adversely the fruit quality. In the past few years, fungicides sold at subsidies increased the expenditure. This fact shows that controlling the fruit diseases is a costly affair. It is therefore essential to find out economical remedial measures so that the fruit industry could be set on a sound footing in the years to come. Failure to achieve this objective may lead to degeneration in the fruit culture of Jammu and Kashmir State and in the due course of time cultivation of fruits trees may become non-remunerative. Some of the important diseases from which the fruit culture in the Rajouri suffers may be listed below.

\section{Apple Scab}

Apple scab, caused by the fungus Venturia inaequalis is a serious disease of apple in Rajouri. It is an annual threat in the wetter interior fruit growing areas. Apple scab has also caused severe losses in the drier areas in years with higher than normal rainfall.

The most serious challenge to the fruits farming was posed by the outbreak of an opiphytotice in 197374 which is known as 'apple scab' disease. This diseases till than was restricted to indigenous varieties like Ambri and red delicious but gradually all the major varieties of apple got infected by the scab. Economic importance of apple cultivation need not be over emphasized in view of the fact that more than twenty percent of the population in the Jammu and Kashmir is either directly or indirectly connected with apple growing for it is the major cash crop. This fact shows that a sizeable proportion of the population depends upon the income derived from orchard mainly apple. In case the incidence of the diseases remains unchecked, it may reduce the market value of apple to the extent that orcharding may become uneconomic. Apple scab diseases are caused by a pathogen which spread under favourable conditions and can be controlled only if necessary chemicals are sprayed regularly at specified time, i.e., from early spring upto three weeks before harvest.

\begin{tabular}{lc} 
Number of spray & Phonological stage of the host \\
\cline { 2 - 2 } First & Green tip \\
Second & Pink bud \\
Third & Petal fall \\
Fourth & Fruit let \\
Fifth & Three weeks after fruit lets \\
Sixth & Three weeks before harvest
\end{tabular}

Therefore, In the light of the problem posed earlier, an immediate attention is need to device an overall strategy so that controlling the diseases may be very much economical and can easily be borne by the orchardists in the absence of any financial assistance from the government. This kind of planning may prove extremely useful for the industry and under these conditions it may have a bright future. 
The numerous insects and non insect pests attacking fruits in Rajouri have never been recorded systematically. The losses in the yield due to their damage have, therefore remained un-noticed for a long time. The 'Sanjose scale' is very well known for its hostility to the apple, but little is known about numerous other pests which are collectively responsible for even greater damage. Thus for effective pest control and forecasting about the pest incursion, detailed information is needed.

Some of the pests are not identifiable and known only by their common names and the extent of damage done to the fruit crops. The host on which each pest has been found to harbor and breed is recorded along with their period of activity and epidemics.

It is quite clear from the table 1 that almost all the varieties of fruits are liable to damage caused by the pests. However in the cases at serial number 2,4 and 6 indicated in the table 1, the damage is of serious nature while in other cases damages generally ranges between minor to medium level of damage to the fruit crops. It is further gathered that the damage is of different nature and affects the different parts of fruit trees differently. Infect these pests are responsible for the colossal losses to the fruit growers as well as the govt. exchequer. Fruit farming communities, some of them are being very poor; have to fight the nuisance on yearly basis despite the fact that they adopt the preventive measures against the damage liable to be caused by the pests.

The present, age of scientific and technology when man has made commendable achievements in the field of fruits culture, particularly in the most advance countries of the world, it is the need of the hour that a detailed study of the various problems relating to the fruits culture in Rajouri should be taken up, so that the multiplication of the pests in the near future should be checked and also suitable measures for the complete eradication of the various pests could be adopted. It may be remarked here that such a programme if executed on government level will go on a long way in curing the diseases from which the fruit industry is suffering. Further it will improve the economic conditions of the fruit growers and help to get the pace of the economic growth of the state.

Table:-1 Insect and Non Insect Pests of Fruits

\begin{tabular}{|c|c|c|c|c|c|c|}
\hline S.No. & Name of the pest & $\begin{array}{c}\text { Name of the } \\
\text { host }\end{array}$ & $\begin{array}{l}\text { Appearance } \\
\text { and active } \\
\text { period } \\
\end{array}$ & $\begin{array}{c}\text { Economic } \\
\text { status }\end{array}$ & $\begin{array}{c}\text { Parts where } \\
\text { damage is } \\
\text { caused } \\
\end{array}$ & Diagnostic symptoms \\
\hline 1 & $\begin{array}{l}\text { Woolly aphis, Eriesoma } \\
\text { lanigerum, (Hausman) } \\
\text { Faimly: Aphididae }\end{array}$ & Apple, & $\begin{array}{c}\text { March } \\
\text { to } \\
\text { November }\end{array}$ & Medium & $\begin{array}{l}\text { Branches and } \\
\text { branch exile, } \\
\text { root and other } \\
\text { damaged } \\
\text { parts of the } \\
\text { tree }\end{array}$ & $\begin{array}{l}\text { White cottony, fibrous } \\
\text { flakes hanging from the } \\
\text { infested parts, gall } \\
\text { formation on roots, } \\
\text { branches, parts of stem } \\
\text { and stunted growth }\end{array}$ \\
\hline 2 & $\begin{array}{l}\text { Sanjose scale, } \\
\text { Quadraspidiotus, } \\
\text { perniciosus, } \\
\text { (Comstock), } \\
\text { Family: coccidae }\end{array}$ & $\begin{array}{l}\text { Apple, Pear, } \\
\text { Peach, Plum, } \\
\text { Almond, } \\
\text { Walnut }\end{array}$ & $\begin{array}{c}\text { April } \\
\text { to } \\
\text { November }\end{array}$ & Serious & $\begin{array}{l}\text { Stem, } \\
\text { branches, } \\
\text { leaves and } \\
\text { fruits }\end{array}$ & $\begin{array}{l}\text { Presence of encrustations } \\
\text { of grayish nipple specks } \\
\text { on infected areas. Drying } \\
\text { of shoots and leaves, red } \\
\text { spots on fruits, shriveled } \\
\text { and wrinkled appearance } \\
\text { of fruits. }\end{array}$ \\
\hline 4 & $\begin{array}{l}\text { Apple green aphis, aphis } \\
\text { pomi, (Degreen) } \\
\text { Family: Aphididae }\end{array}$ & Apple & $\begin{array}{l}\text { Mid of march } \\
\text { to ending } \\
\text { October }\end{array}$ & Serious & $\begin{array}{l}\text { Leaves tender } \\
\text { shoots and } \\
\text { terminal } \\
\text { portion of the } \\
\text { tree }\end{array}$ & $\begin{array}{l}\text { Numerous green slender } \\
\text { bodied insects' presents } \\
\text { on tips, curling of leaves, } \\
\text { withering of branches } \\
\text { sooty black colour of } \\
\text { leaves and branch tips. }\end{array}$ \\
\hline 5 & $\begin{array}{l}\text { Mealy plums aphis, } \\
\text { Hvalopterus, }(\mathrm{F}) \\
\text { Family: Aphididae }\end{array}$ & Plum & $\begin{array}{c}\text { April } \\
\text { to } \\
\text { September }\end{array}$ & Medium & $\begin{array}{l}\text { Leaves tender } \\
\text { shoots and } \\
\text { buds }\end{array}$ & $\begin{array}{l}\text { Small green insects with } \\
\text { specks of white powdery } \\
\text { dust on the body, curling } \\
\text { and drying of leaves. }\end{array}$ \\
\hline
\end{tabular}




\begin{tabular}{|c|c|c|c|c|c|c|}
\hline 8 & $\begin{array}{l}\text { Walnut leaf aphis, } \\
\text { Callipteras, Jaglandis, } \\
\text { (Frisch) } \\
\text { Aphididae }\end{array}$ & Walnut & $\begin{array}{c}\text { May } \\
\text { to } \\
\text { October }\end{array}$ & Minor & $\begin{array}{l}\text { Upper surface } \\
\text { of the leaves }\end{array}$ & $\begin{array}{l}\text { Presence of green lice on } \\
\text { the mid rib and lamina, } \\
\text { drying of leaves }\end{array}$ \\
\hline
\end{tabular}

Source: Malik, R.A. et al., "Survey study of insects and non insect's pests in Jammu and Kashmir" Horticulturist, Vol.III, No. 1-3, pp 28-31.

Table:-2 Fungal and Bacterial Diseases of Fruit Crops and Their Management

\begin{tabular}{|c|c|c|c|c|c|}
\hline S.no. & $\begin{array}{l}\text { Name of the } \\
\text { fungus/bacteria }\end{array}$ & $\begin{array}{l}\text { Name of } \\
\text { the host }\end{array}$ & $\begin{array}{l}\text { Symptoms } \\
\text { appearing }\end{array}$ & Damage & $\begin{array}{l}\text { Measures and } \\
\text { management }\end{array}$ \\
\hline 1 & $\begin{array}{l}\text { Peach leaf-curi } \\
\text { Taphruna deformans }\end{array}$ & $\begin{array}{l}\text { Plum, } \\
\text { almond, } \\
\text { and } \\
\text { peach }\end{array}$ & $\begin{array}{l}\text { Curing, } \\
\text { puckering and } \\
\text { distortion of } \\
\text { young leaves, } \\
\text { The infected } \\
\text { parts develop } \\
\text { pink or red } \\
\text { bronze colour. } \\
\text { Young twigs are } \\
\text { swollen, turn } \\
\text { pale and are } \\
\text { killed }\end{array}$ & $\begin{array}{lr}\text { It } & \text { reduces } \\
\text { plant } & \text { vigour } \\
\text { and } & \text { fruit } \\
\text { yield. } & \end{array}$ & $\begin{array}{l}\text { Prune off the affected } \\
\text { twigs, spray of copper } \\
\text { exychloride, carbendazim } \\
\text { or Bitertanol during late } \\
\text { dormancy just before bud } \\
\text { swell. }\end{array}$ \\
\hline 2 & $\begin{array}{llr}\begin{array}{l}\text { Brown rot } \\
\text { blossom and } \\
\text { manliza laxa }\end{array} & \\
\text { blight }\end{array}$ & $\begin{array}{l}\text { Plum, } \\
\text { and } \\
\text { peach }\end{array}$ & $\begin{array}{l}\text { Small, circular } \\
\text { brown spot } \\
\text { appears on } \\
\text { fruits }\end{array}$ & $\begin{array}{l}\text { Wilting of the } \\
\text { young } \\
\text { branches, } \\
\text { affects plant } \\
\text { health, lowers } \\
\text { fruit yield and } \\
\text { quality. }\end{array}$ & $\begin{array}{l}\text { Spray Carbendazim for } \\
\text { controlling blossom blight } \\
\text { or wilt. }\end{array}$ \\
\hline 3 & $\begin{array}{l}\text { Bacterial gummosis } \\
\text { Pseudomonas spp }\end{array}$ & $\begin{array}{l}\text { Almond, } \\
\text { apricot } \\
\text { and } \\
\text { peach }\end{array}$ & $\begin{array}{l}\text { Circular to } \\
\text { elongate Water- } \\
\text { soaked, } \\
\text { gumming } \\
\text { lesions on bark } \\
\text { or } \\
\text { sapwood outer } \\
\text { trunk. }\end{array}$ & $\begin{array}{l}\text { Reduces fruit } \\
\text { yield and fruit } \\
\text { quality }\end{array}$ & $\begin{array}{l}\text { Clean the weeping } \\
\text { wounds, apply Mashobra } \\
\text { paste, streptocycline and } \\
\text { copper oxychloride }\end{array}$ \\
\hline 4 & $\begin{array}{l}\text { Mildew Sphaerotheca } \\
\text { pannosd and } \\
\text { Podosphaera } \\
\text { Oxycantha }\end{array}$ & $\begin{array}{l}\text { Plum, } \\
\text { almond, } \\
\text { apricot }\end{array}$ & $\begin{array}{l}\text { White mealy } \\
\text { powder appears } \\
\text { on the young } \\
\text { leaves and } \\
\text { current year's } \\
\text { growth. }\end{array}$ & $\begin{array}{l}\text { The growth of } \\
\text { infected } \\
\text { leaves, buds } \\
\text { and shoots is } \\
\text { reduced. }\end{array}$ & $\begin{array}{l}\text { Spray wattable sulphur or } \\
\text { Carbendazim/Thiophanate } \\
\text { methyl before blossoms } \\
\text { open, at the petal fall and } \\
2 \text { weeks later. }\end{array}$ \\
\hline 5 & $\begin{array}{l}\text { Frosty mildew } \\
\text { Cercosorella persicae }\end{array}$ & $\begin{array}{l}\text { Plum, } \\
\text { almond, }\end{array}$ & $\begin{array}{l}\text { Small, white, } \\
\text { powdery spots } \\
\text { on the lower } \\
\text { sides of leaves }\end{array}$ & $\begin{array}{l}\text { Pre-mature } \\
\text { yellowing and } \\
\text { mad } \\
\text { defoliation. } \\
\end{array}$ & $\begin{array}{l}\text { Spray Mancozeb in } \\
\text { August and September }\end{array}$ \\
\hline 6 & $\begin{array}{l}\text { Stigmina blight } \\
\text { Stigmina Carpophylla }\end{array}$ & $\begin{array}{l}\text { Plum, } \\
\text { apricot }\end{array}$ & $\begin{array}{l}\text { Light yellow to } \\
\text { reddish spots } \\
\text { appear on } \\
\text { leaves }\end{array}$ & $\begin{array}{l}\text { Reduces fruit } \\
\text { yield and fruit } \\
\text { quality }\end{array}$ & $\begin{array}{l}\text { Spray trees with Cooper } \\
\text { oxychloride before leaf } \\
\text { fall and bud swell. }\end{array}$ \\
\hline 7 & $\begin{array}{l}\text { Rust Trianzchelia } \\
\text { Discolar }\end{array}$ & $\begin{array}{l}\text { Plum, } \\
\text { apricot } \\
\text { and } \\
\text { peach }\end{array}$ & $\begin{array}{lr}\text { Rusty } & \text { pustules } \\
\text { appear } & \text { on } \\
\text { leaves. } & \\
\end{array}$ & $\begin{array}{l}\text { early fall of } \\
\text { leaves }\end{array}$ & $\begin{array}{l}\text { Spray Mancozeb at } 20 \\
\text { days interval from petal } \\
\text { fall. }\end{array}$ \\
\hline 8 & $\begin{array}{l}\text { Silver leaf canker } \\
\text { Chondrostereum } \\
\text { purpureum }\end{array}$ & $\begin{array}{l}\text { Plum, } \\
\text { almond, } \\
\text { apricot } \\
\text { and } \\
\text { peach }\end{array}$ & $\begin{array}{l}\text { peculiar silvery } \\
\text { luster instead of } \\
\text { normal green } \\
\text { colour }\end{array}$ & $\begin{array}{l}\text { The papery } \\
\text { brown canker } \\
\text { affects the } \\
\text { limb of tree. }\end{array}$ & $\begin{array}{l}\text { Proper fertilization of } \\
\text { plants, Cover fresh } \\
\text { wounds on trees with } \\
\text { Copper oxychloride paint }\end{array}$ \\
\hline 9 & $\begin{array}{l}\text { Wishker's rot } \\
\text { Rhizopus stolonifer. }\end{array}$ & $\begin{array}{l}\text { Plum, } \\
\text { almond, } \\
\text { apricot } \\
\text { and } \\
\text { peach }\end{array}$ & \begin{tabular}{l}
\multicolumn{2}{l}{ Water-soaked } \\
spots, rot \\
covered with \\
the fungus \\
bearing black \\
fruiting bodies.
\end{tabular} & $\begin{array}{l}\text { Fruits are } \\
\text { rotten }\end{array}$ & $\begin{array}{l}\text { proper care while handing } \\
\text { fruits to avoid bruises. }\end{array}$ \\
\hline
\end{tabular}




\begin{tabular}{|c|c|c|c|c|c|}
\hline 10 & $\begin{array}{l}\text { Bacterial leaf spot and } \\
\text { fruit gummosis of } \\
\text { almond Xanthomonas } \\
\text { campestris pv. Pruni }\end{array}$ & Almond & $\begin{array}{l}\text { Angular leaf } \\
\text { spot of brown } \\
\text { colour and } \\
\text { circular brown } \\
\text { spots on leaves } \\
\text { during rainy } \\
\text { season }\end{array}$ & & $\begin{array}{l}\text { sprays of Strep and } \\
\text { copper oxychloride } \\
\text { tocycline at } 15 \text { days } \\
\text { interval }\end{array}$ \\
\hline 11 & $\begin{array}{l}\text { Sclerotius bligh } \\
\text { Sclerotuim rolfsii. }\end{array}$ & $\begin{array}{l}\text { Apple } \\
\text { and Pear }\end{array}$ & $\begin{array}{l}\text { Small mustard } \\
\text { colored } \\
\text { sclerotia appear } \\
\text { at the collar } \\
\text { region during } \\
\text { monsoon. }\end{array}$ & $\begin{array}{l}\text { Infected } \\
\text { seedlings are } \\
\text { killed rapidly. }\end{array}$ & $\begin{array}{l}\text { Uproot affected seedling } \\
\text { and destroy, Nursery site } \\
\text { should be changed } \\
\text { regularly and fumigated. }\end{array}$ \\
\hline 12 & $\begin{array}{l}\text { Crown } \\
\text { Agrobacterium } \\
\text { tumerfaciens. }\end{array}$ & $\begin{array}{l}\text { Apple } \\
\text { and Pear }\end{array}$ & $\begin{array}{l}\text { Globular, } \\
\text { elongated or } \\
\text { irregular tumors } \\
\text { are formed at or } \\
\text { near the graft- } \\
\text { union mainly in } \\
\text { nursery plants. }\end{array}$ & $\begin{array}{l}\text { Plant growth } \\
\text { is affected. }\end{array}$ & $\begin{array}{l}\text { Biocontrol with a related } \\
\text { strain of bacterium is } \\
\text { being practiced. }\end{array}$ \\
\hline \multirow[t]{2}{*}{13} & $\begin{array}{l}\text { White root rot } \\
\text { Dematophora } \\
\text { necatrix. }\end{array}$ & Pear & $\begin{array}{l}\text { Bronzing and } \\
\text { yellowing of } \\
\text { leaves }\end{array}$ & $\begin{array}{l}\text { Death of } \\
\text { trees. }\end{array}$ & $\begin{array}{l}\text { Proper maintenance of the } \\
\text { drainage. }\end{array}$ \\
\hline & $\begin{array}{l}\text { Collar-rot } \\
\text { Phytophthora } \\
\text { cactorum. }\end{array}$ & & $\begin{array}{l}\text { Collar region } \\
\text { near the ground } \\
\text { level turns } \\
\text { brown, soft and } \\
\text { spongy in } \\
\text { poorly drained } \\
\text { soil }\end{array}$ & $\begin{array}{l}\text { Affects fruits } \\
\text { yield } \\
\text { adversely in } \\
\text { the beginning } \\
\text { and trees } \\
\text { ultimately } \\
\text { die. }\end{array}$ & $\begin{array}{l}\text { During dormant period } \\
\text { remove the soil around } \\
\text { the collar region and } \\
\text { expose the affected } \\
\text { portion }\end{array}$ \\
\hline 14 & $\begin{array}{l}\text { Cankers and die-back } \\
\text { diseases (pink canker) } \\
\text { Botryobasidium } \\
\text { salmonicolor, } \\
\text { European canker } \\
\text { Black rot (smoky } \\
\text { blight) } \\
\text { Botryosphaeria } \\
\text { quercum Nail head } \\
\text { Nummularia Stem } \\
\text { black Coniothecium } \\
\text { Silver leaf } \\
\text { Chondrosterm } \\
\text { purpureum } \\
\text { brown or stem bark } \\
\text { canker } \\
\text { Botryosphaeria } \\
\text { dothidea caused by } \\
\text { various fungi. }\end{array}$ & Apple & $\begin{array}{lr}\text { open } & \text { wounds } \\
\text { and } & \text { deep } \\
\text { sunken lesions } \\
\text { on the bark }\end{array}$ & $\begin{array}{l}\text { The tree } \\
\text { becomes } \\
\text { weak, and } \\
\text { limb and fruit } \\
\text { yield is } \\
\text { reduced. }\end{array}$ & $\begin{array}{l}\text { Cut and burn the badly } \\
\text { cankered portions of the } \\
\text { trees, Spray schedule } \\
\text { adopted for apple scab } \\
\text { also helps in reducing its } \\
\text { incidence. Prune off } \\
\text { terminals covered by } \\
\text { powdery mildew and } \\
\text { destroy them. }\end{array}$ \\
\hline 15 & $\begin{array}{l}\text { Powdery mildew } \\
\text { Podospharea } \\
\text { ieucotricha }\end{array}$ & Apple & $\begin{array}{l}\text { White powdery } \\
\text { growth on buds, } \\
\text { and leaves. }\end{array}$ & $\begin{array}{lr}\begin{array}{l}\text { Affects } \\
\text { growth }\end{array} & \text { the } \\
\text { buds, } & \text { new } \\
\text { shots } & \text { and } \\
\text { leaves } & \\
\end{array}$ & $\begin{array}{llr}\text { Spraying } & \text { of fungicides, } \\
\text { Apple } & \text { scab spray } \\
\text { schedule } & \text { reduces the } \\
\text { disease. } & & \end{array}$ \\
\hline 16 & $\begin{array}{l}\text { Leaf } \\
\text { Mycosphaerella spots } \\
\text { Alternaria mali, A. } \\
\text { alternate, } \\
\text { Coniothyrium } \\
\text { pyrinum. Phyllosticta } \\
\text { spp, and } \\
\begin{array}{l}\text { Botryosphaeria } \\
\text { quercum }\end{array}\end{array}$ & Apple & $\begin{array}{l}\text { Spots of various } \\
\text { types, colour, } \\
\text { size and shape } \\
\text { are of common } \\
\text { occurrence on } \\
\text { the leaves } \\
\text { during late } \\
\text { summer and } \\
\text { rainy season }\end{array}$ & $\begin{array}{l}\text { Heavily } \\
\text { spotted leaves } \\
\text { turn yellow } \\
\text { and fall } \\
\text { prematurely. }\end{array}$ & $\begin{array}{l}\text { Spray schedule adopted } \\
\text { for apple scab can } \\
\text { controls leaf spots. }\end{array}$ \\
\hline
\end{tabular}




\begin{tabular}{|c|c|c|c|c|c|}
\hline 17 & $\begin{array}{l}\text { Apple scab Venturia } \\
\text { inaequalis (Spilocea } \\
\text { pomi) }\end{array}$ & $\begin{array}{l}\text { Apple } \\
\text { and Pear }\end{array}$ & $\begin{array}{l}\text { Light brown or } \\
\text { olive green, } \\
\text { round spots } \\
\text { with a velvety, } \\
\text { distinct outline } \\
\text { appear on either } \\
\text { or both sides of } \\
\text { the young } \\
\text { leaves in spring. }\end{array}$ & $\begin{array}{lr}\text { It } & \text { affects } \\
\text { shape, } & \text { size } \\
\text { shelf-life } & \text { and } \\
\text { quality } & \text { of } \\
\text { fruits } & \end{array}$ & $\begin{array}{l}\text { Collect and burn fallen } \\
\text { leaves during winter, } \\
\text { Spray urea }\end{array}$ \\
\hline 18 & $\begin{array}{l}\text { Sooty blotch and fly } \\
\text { speck Gloeodes } \\
\text { promigens and } \\
\text { Schizothyrium pomi }\end{array}$ & Apple & $\begin{array}{l}\text { Both the } \\
\text { diseases appear } \\
\text { as sooty } \\
\text { blemishes on } \\
\text { the external } \\
\text { surface of fruits } \\
\text { especially under } \\
\text { high humidity } \\
\text { during rainy } \\
\text { season }\end{array}$ & $\begin{array}{lr}\text { It } & \text { lowers } \\
\text { down the } \\
\text { market value } \\
\text { of fruits. }\end{array}$ & $\begin{array}{l}\text { Spray schedule followed } \\
\text { for the management of } \\
\text { apple scab provides } \\
\text { effective control of these } \\
\text { diseases. }\end{array}$ \\
\hline 19 & $\begin{array}{l}\text { Fruit rots (blue mould } \\
\text { rot) Penicillium } \\
\text { expansum, Bitter rot } \\
\text { Glomerella cingulata, } \\
\text { Brown rot Monilinia } \\
\text { fruitigena, } \\
\text { mould Pink } \\
\text { Trichothecium rot } \\
\text { roseum. Whiskers rot } \\
\text { Rhizopus stolonifer, } \\
\text { Bot rot } \\
\text { Botryosphaeria } \\
\text { dothidea, Black-rot } \\
\text { Bguercum and Dry } \\
\text { rot Alternaria sp. }\end{array}$ & $\begin{array}{l}\text { Apple } \\
\text { and pear }\end{array}$ & $\begin{array}{l}\text { Fruit rots results } \\
\text { into } \\
\text { rotting/decay, } \\
\text { twifts, black } \\
\text { dots, growth of } \\
\text { white fungal } \\
\text { threads. }\end{array}$ & $\begin{array}{l}\text { Fruits develop } \\
\text { various types } \\
\text { of rots either } \\
\text { in the field or } \\
\text { storage } \\
\text { resulting into } \\
\text { huge } \\
\text { economic } \\
\text { losses. }\end{array}$ & $\begin{array}{l}\text { Removal and destruction } \\
\text { of infected fruits. }\end{array}$ \\
\hline
\end{tabular}

Source: Hand Book of Kashmir Horticulture

Table:-3 Viral Diseases of Fruit crops and Their Management

\begin{tabular}{|c|c|c|c|c|c|}
\hline $\begin{array}{l}\mathbf{S} \\
\dot{\mathbf{N}} \\
\mathbf{0}\end{array}$ & $\begin{array}{l}\text { Name of the } \\
\text { virus/Pytoplasm }\end{array}$ & $\begin{array}{l}\text { Name of } \\
\text { the host }\end{array}$ & Symptoms appearing & Damage done & Measures and management \\
\hline 1 & $\begin{array}{l}\text { Tristeza Transmitted by } \\
\text { aphids. }\end{array}$ & Citrus & $\begin{array}{l}\text { Chlorotic spots and dashes } \\
\text { along lateral veins and vein } \\
\text { lets }\end{array}$ & Causing losses in yield & $\begin{array}{l}\text { Eradicate and destroy all } \\
\text { infected plants or seedling } \\
\text { yellows, Use virus-free planting } \\
\text { material. }\end{array}$ \\
\hline 2 & $\begin{array}{l}\text { Crinkly leaf Transmitted } \\
\text { by aphids. }\end{array}$ & Lemon & $\begin{array}{l}\text { Pinhead-sized circular spots on } \\
\text { newly-emerging leaves }\end{array}$ & Development crinkling & $\begin{array}{l}\text { Use induced planting material } \\
\text { and remove infected plants from } \\
\text { the field }\end{array}$ \\
\hline 3 & $\begin{array}{l}\text { Mosaic Transmitted by } \\
\text { grafting. }\end{array}$ & $\begin{array}{l}\text { Lemon } \\
\text { and } \\
\text { orange }\end{array}$ & $\begin{array}{l}\text { leaves and fruits with yellow } \\
\text { and green patches }\end{array}$ & $\begin{array}{lr}\text { Infected } & \text { plants are } \\
\text { stunted, } & \text { reducing } \\
\text { yield. } & \end{array}$ & $\begin{array}{l}\text { Use virus-free planting material. } \\
\text { Control aphid vectors through } \\
\text { insecticides }\end{array}$ \\
\hline 4 & $\begin{array}{l}\text { Veinenation and woody } \\
\text { gall Transmitted by } \\
\text { aphids. }\end{array}$ & Lemon & $\begin{array}{l}\text { Show swelling to conspicuous } \\
\text { projection on veins of the } \\
\text { undersurface of leaves }\end{array}$ & $\begin{array}{l}\text { The disease causes } \\
\text { stunting of plants } \\
\text { causing losses in yield. }\end{array}$ & Use virus-free planting material \\
\hline 5 & $\begin{array}{l}\text { Greening Transmitted by } \\
\text { citrus psylla. }\end{array}$ & $\begin{array}{l}\text { Lemon } \\
\text { and } \\
\text { orange }\end{array}$ & $\begin{array}{l}\text { Vein chlorotic } \\
\text { irregular yellowing }\end{array}$ & $\begin{array}{l}\text { Fruit are of very poor } \\
\text { quality with inspid or } \\
\text { bitter juice. }\end{array}$ & $\begin{array}{l}\text { Use disease-free planning } \\
\text { material. }\end{array}$ \\
\hline 6 & $\begin{array}{l}\text { Exocortis Transmitted } \\
\text { by contaminated tools. }\end{array}$ & Lemon & Split in the bark & $\begin{array}{l}\text { The disease may cause } \\
\text { yield losses }\end{array}$ & $\begin{array}{l}\text { Use disease-free planting } \\
\text { material. Complete sterilization } \\
\text { of tools during operation. Use } \\
\text { tolerant rootstocks. }\end{array}$ \\
\hline
\end{tabular}




\begin{tabular}{|c|c|c|c|c|c|}
\hline 7 & $\begin{array}{l}\text { Xyloporosis Transmitted } \\
\text { by contaminated tools. }\end{array}$ & & $\begin{array}{l}\text { Pitting and pegs on the } \\
\text { cambial surface of the bark }\end{array}$ & yield losses & $\begin{array}{l}\text { Use disease-free planting } \\
\text { material. Complete sterilization } \\
\text { of tools during operation. Use } \\
\text { tolerant rootstocks. }\end{array}$ \\
\hline 8 & Infectious variegation & $\begin{array}{l}\text { Sour } \\
\text { orange } \\
\text { and } \\
\text { lemon. }\end{array}$ & $\begin{array}{l}\text { Small translucent spots } \\
\text { distributed all over the leaf }\end{array}$ & $\begin{array}{l}\text { This disease is of } \\
\text { minor importance. }\end{array}$ & Use virus-free bud wood \\
\hline 9 & Blastomania & $\begin{array}{l}\text { Orange } \\
\text { and } \\
\text { lemon. }\end{array}$ & $\begin{array}{l}\text { Reduced leaf size, leaves } \\
\text { forming a cluster-like bouquet. }\end{array}$ & $\begin{array}{l}\text { The disease may cause } \\
\text { total yield loss }\end{array}$ & $\begin{array}{l}\text { spraying of Oxytetracycline } \\
\text { hypochloride } \\
(250 \mathrm{ppm}) \text {, times at weekly } \\
\text { intervals. }\end{array}$ \\
\hline $\begin{array}{l}1 \\
0\end{array}$ & Psorosis & $\begin{array}{l}\text { Orange } \\
\text { and } \\
\text { lemon. }\end{array}$ & $\begin{array}{l}\text { Typical leaf flecking, small } \\
\text { cleared spots and bands of } \\
\text { lighter colour on young soft } \\
\text { leaves }\end{array}$ & Reducing yield. & $\begin{array}{l}\text { Use virus-free planting material. } \\
\text { Use nuclear clones. }\end{array}$ \\
\hline
\end{tabular}

Source: Hand Book of Kashmir Horticulture

Fruits products being fleshy, succulent and tender are very much prome to the attack of diseases causing fungus and bacteria's. More so more products are produced in near vicinity of the soil posing vulnerability to be attacked by the diseases. The ravage by diseases cause great loss of labour and money input every year in Jammu and Kashmir.

\section{Boron Deficiency Affecting Fruits}

Boron, for long, is recognized as one of the essential element for the plant growth. Though needed in relatively small quantities, its deficiency adversely affecting plants growth and fruits yield and quality is very commonly encountered in the orchards of Jammu and Kashmir. Deficiency symptoms have been commonly recorded in such fruit crops as apple, pear, peach, plum, and apricot. Boron is present in extremely small quantities in most of soils and generally occurs in borosilicate containing varying amount of iron, aluminum, magnesium, manganese, calcium, lithium and sodium. Release of boron from this mineral is very slow. The available soil boron is held by the organic fraction and is released by the organic matter decomposes. Part of it is taken by plants and part is lost by leaching.

There are several factors which affect the boron availability in the soil. The most important factors are the soil texture, $\mathrm{PH}$ and moisture.

\section{Soil texture}

Coarse textured, well drained soil is low in boron. This is because of the clay fraction in the soil in some manners retains boron. However, this does not mean that plants absorb boron from clays in greater quantities than from sands when equal concentration of boron is present. Infect plants have been found to take of much larger quantities of boron from sandy soils than from fine textured soils at equal concentration of water soluble boron.

\section{Soil pH}

Symptoms of boron deficiency are associated with high $\mathrm{pH}$ values and boron uptake by plants is reduced by increasing soil $\mathrm{pH}$. $\mathrm{pH}$ is directly related to the lime level of the soil. Some workers associate the ill affect of high soil $\mathrm{pH}$ to reduce the availability of boron and others associate it to unfavorable calcium: boron ratio.

\section{Soil moisture}

Boron deficiency is more pronounced under extremely dry soil conditions. This is perhaps the reason for greater symptom expression of boron deficiency during 1969-71, which were usually dry years for the Kashmir valley.

\section{Symptoms of the boron deficiency}

In general visual symptoms of the boron deficiency are more severe on fruits than on the vegetative part of the fruit trees. The symptoms relating to boron deficiency in fruits may be indicated as under.

The fruit develops internal or external cork. The internal cork develops any time after fruits set to harvest. If it develops early the internal lesion of boron, round or irregular in shape with well defined margins. 
Apple

Internal or external cork develops on the fruits. The internal cork develops any time after fruit set to harvest. If it develops early the internal lesions are brown, round or irregular in shape with well defined margins. The fruits remain small irregular in shape and may drop prematurely. The deformed fruits are commonly seen in varieties such as Ambri, Baldwin, White Dotted Red and Gillyflower and are usually called as 'Monkey fruits'.

The seasonal internal corks develop internal lesions with less sharply defined margins and are soft and spongy. There may be no internal evidence of late season internal cork. External cork develops soon after bloom. In the early stages the affected areas appear water soaked. The lesions are superficial but, because growth stops in affected areas, the fruit often is disshaped, cracked and dwarfed. Cracking of fruits is often in boron deficit apple variety Baldwin where deep corky furrows may result. Thus there is heavy premature drop of affected fruits. Boron deficiency also affects the blossoming. In Ambri variety this often lead to blossom blast and thereby results in poor setting. Vegetative symptoms usually occur under very severe deficiency. These are marked by shortening of the shoots and dwarfing of leaves, a condition often referred to as 'Rosettes'. Such rosettes develop any time of the season. This is often followed by die back of shoots in late summer. Cracking of the bark on the stem and branches also results from boron deficiency. Such symptoms have been seen on the ambri apple variety.

Boron deficiency caused shallow depressions anywhere on the fruit surface and more especially towards the calyces end. In severe cases there is malformation and cracking of fruits. Boron deficiency affecting at blossom time results in poor fruit set. Deficiency symptoms exhibited by the vegetative parts are marked by reduce shoot growth. The basal leaves fail to develop and the terminal leaves are dwarfed.

Plum

Symptoms of boron deficiency have commonly been observed in Rajouri and Kashmir on the grand duke variety of plum. As a general rule European plums are supposed to be more susceptible to expression of boron deficiency symptoms than the Japanese plums. In general, boron deficiency in plum results in malformed fruits with brown spotting almost like sunburn. A brown sunken area may form on the flesh as single spot or may extend to whole of the fruit. Under severe deficiency the brown affected area may extend to the pit. The affected fruits colour early and there is a heavy premature drop.

The vegetative symptoms are characterized by die-back of the terminal twigs, some time resulting in a condition described as 'bush branch' because after the terminal dies the lateral buds from new shoots which in turn die-back. This condition is more commonly seen in prunes. The leaves are dwarfed, curled up at the margins and are often blackened at the tip soon after they are formed. The affected leaves in general are narrow.

\section{Apricot}

Boron deficiency symptoms are more readily exhibit by apricots as compared to plum. The symptoms of boron deficiency as exhibited by the fruits are internal browning and formation of corky tissue in the pericarp around the cavity. It extends upto varying distances into the flesh. There may also be external cracking of the fruit. External browning, shriveling and acute malformation of the fruit surface may also be observed.

Vegetative symptoms under severe deficiency are characterized by dying back of terminal twigs later in the season. A characteristic shoot-holing of the terminal twigs is also observed.

\section{Removal of the deficiency}

Deficiency of Boron in apple can be removed either by soil or foliar application. A spray of one kilogram borax in 100 gallons of water has given affective control of symptoms expression due to boron deficiency of apple in Jammu and Kashmir. Foliar sprays of three $1 \mathrm{bs}$. Borax per 100 gallons of water sprayed at pre-bloom every third year is also a recommended practice. The orchardists using a chemical fertilizer, soil or foliar application, need to be cautioned that only a narrow margin occur between deficiency and toxicity of boron. Over fertilization by boron may lead to complicacies.

\section{Fruit Marketing and Related Problems}

An important problem of the Jammu and Kashmir relates to the marketing of its fruits, which are cultivated on commercial scale. With a view to enhance the income of the fruit growers in particular and the state in general, it is extremely essential that the relevant problems in respect of disposal off fresh and dry fruits should be thoroughly studied under the existing facilities for their marketing and possible solutions may be arrived at. In the absence of proper marketing facilities, it is very likely that production in due course of time may adversely be affected. Marketing of fruits may be considered at two levels vis., (1) supply of the fresh and dry fruits to the local markets for consumption within the state (2) purchase of the commodities in bulk by the 
buyers for their marketing outside the state. The fresh fruits can also converted into James, Jellies, squashes, where facilities for preservation exist.

In a state like Jammu and Kashmir which is connected with India by highly mountainous terrain, supply of fruits (Fresh and dry) to market outside the state is not only difficult but also very expensive. For the last many decades, it has been observed that trucks provide the only means for the disposal of fruits, (fresh and dry both) to different parts of India. However, about ninety per cent of the fruit sold to outside buyers, reaches Delhi centre, from where they are distributed to various markets in the country. Only ten per cent is sent directly from Jammu and Kashmir to other important towns of the country. Fruits sold to big buyers at low rates in Jammu and Kashmir become very costly in the big cities of India. In this way the poor fruit growers are the real losers and the intermediaries are the main beneficiaries.

\section{Problems of Major Collection and Disposal Centers}

Among the fresh fruits of Jammu and Kashmir, apple is marketed seventy to eighty per cent outside the state. The other categories of fresh fruits are in less demand and as such their export accounts for about four to nine per cent of the total fresh fruits produced in the state. Dry fruits are also exported to different parts of the country. They include generally walnut and almond. Their export ranges between fifteen and thirty per cent. As far as the collection and disposal of fresh fruits is concerned, it is customary that after harvesting the fruits in the orchards, they are graded according to size, colour and variety at the points of production, and then they are packed in the wooden boxes. Each box contains about fifteen to twenty kg. vis., apple, apricot, plum, pear, peach and six to eight kg., Cherry.

Beside the size of the orchard and distance involved in the marketing, from the orchard to the point of collection, grading and packing are always done in the orchard wooden boxes are used. If the fruit is meant for local market, grading off fruits may be avoided but packing will always be done. In certain parts of the state, orchards are not directly connected with the first class metelled road, hence the fruits containers are transported with tongas, and other available vehicles but on the main roads transportation is always done through trucks which may either be hired or the contractors may have their own trucks for this purpose. It has also been observed that there are some villages in the interior which are not connected even with unmetelled roads in these areas, after packing up of the fruits, boxes are carried up to the loading spot by the local laborers and at a time two fruit boxes can be carried. This procedure is really very troublesome and also expensive. Nevertheless in the absence of some alternative solution, this has to be followed. It is very strange that there is low facility for collection and disposal of fresh fruits. Major produce of the fresh fruits is graded and packed in the orchards from where they are marketed to outside the state but in the case of dry fruits, collection centre are essential. From different parts dry fruits are collected and stored at some important places. In case of walnut, hulling and drying centre are very important where necessary processing is done. For example walnut quality is largely determined in two weeks time after harvest. During this time nuts should be hulled, dried from forty per cent moisture to five cent and than graded. In case of nuts that remain unshelled are treated with per cent of the profit is snatched away by the intermediaries. A few other problems may be listed below.

\section{Buying and Selling Malpractices}

Most of the fruit growers own lands ranging between one to two hectares which is mainly devoted to apples being their cash crops. Thus procurement of fruits, from thousands of such small growers and their distribution to distant markets, is really a tough and complicated problem. With the result that it involves a good many intermediaries, including preserves contractors, forwarding and commission agents and a series of wholesale and sub-whole-sale merchants. As the small individual growers, have very little knowledge about marketing, it becomes rather difficult to arrange transport for disposal in the market. Being poor, they usually need cash before harvest. Thus about two-thirds of the growers sell their crop to preharvest contractors. Such sales take place soon after fruit setting in the tress starts. The growers are given some advance and the balance is paid in several installments. This is all partly because small growers, are poor, and illiterate and hence have little bargaining power and partly due to the fact that preharvest contractors, allow a reasonable margin, to cover risks against natural calamities like hailstorm and scabs.

Table:-4 Farm and Market Prices of Fruits (Per 100 kg)

\begin{tabular}{|c|c|c|c|}
\hline S.No. & Name of the fruit & Farm Price & Market Price \\
\hline 1 & Apple & 1500 & 2800 \\
\hline 2 & Pear & 1000 & 1900 \\
\hline 3 & Peach & 900 & 1700 \\
\hline 4 & Plum & 1200 & 2200 \\
\hline 5 & Apricot & 1000 & 2000 \\
\hline
\end{tabular}




\begin{tabular}{|c|c|c|c|}
\hline 6 & Walnut & 5000 & 11000 \\
\hline 7 & Almond & 6000 & 13000 \\
\hline 8 & Ber & 800 & 1300 \\
\hline 9 & Mango & 1200 & 2500 \\
\hline
\end{tabular}

One of the major problems is that the prices paid to the growers are always low. The growers are deprived of direct access to the market and the maximum return of their products. Co-operative societies may be the only organization which can take care of the poor growers with a view to save them from exploitation. A network of such societies in the area may help to solve the immediate problems of the poor small growers to some extent.

\section{Lack of Grading and Standardization}

It is always observed that merchants do not have faith in the growers. That is why fruits are not graded according to the standard specification, because, in respect of grading practices followed at the point of production. As a result fruits are regraded and repacked, each time it change hands in the marketing chain, depending upon the situation and the sweet will of the merchants. Thus the produce, which comes generally to the market, is a mixture of different qualities and grades of fruit and as such it becomes difficult to assign prices to these goods on the basis of qualities and grades. It follows from this fact that prices and quality of produce have no direct relationship between them. The growers, therefore, find it difficult to secure higher returns for their superior quality products. As a result the growers engaged in the production of quality fruits very often get discouraged and the consumers too get no satisfaction from such transactions. If grading is done according to the specific norms, through the fruit growers co-operative societies, it will definitely fetch higher returns for the quality products in the market.

Another problem is the inadequate transport facilities from the production centres to the markets, which are expected to receive commodities from the market, are located at distances far away from the point of production. Railway facilities are available up to Jammu only. From Jammu all other fruits growing districts are located far away and involves many hours continuous Journey, in highly mountainous terrain. Many times, it takes more then a couple of days when the road is blocked owing to land slide. This happens generally during the rainy season and also in the winter months when snowfalls dislocates the traffic. In case the fruit is sent by trucks to distant markets like Mumbai, Bangalore, Kolkata, and Chennai. Freight charges will be very high besides the additional charges that may be levied on account of the detentions of trucks is the transit due to road blockade. The cost of the fruits will increases manifold on account of such difficulties, another problem will also come up i.e., delay in the transit may cause spoilage of the packed fruits loaded on the trucks. The delay in the delivery of the fresh fruits to the markets may further create problems because the temperature conditions in the plain area will be relatively high and as such there is ever likelihood that the fruits while reaching the distant markets may be much more destroyed.

Some of the commission agents arranged for unloading their commodities at Jammu Railway stations but due to the inefficiency of the railway services, it has been observed many a times that there is much loss which the owners or the contractors may have to incur. In view of this fact dispatch through railway carriages is usually not favored by the contractors or by the owners.

\section{Inadequate facilities of Cold storage}

In the state of Jammu and Kashmir there are problems of inadequate cold storage facilities for fresh fruits. It has been observed from the field studies that only a small percentage of the fresh fruits can be kept in the cold storage for off-season marketing. The quantity that finds accommodation in the cold storage does not suffice the need of the customers. On account of non-availability of required number of cold storages, many of the growers after harvesting the fruits, like pear, peach and especially apple, store them in orchards where spoilage, is usually very high because of dampness, high temperature and humidity problem.

It has been estimated that about 10 to 25 per cent of fruits are destroyed in this way depending upon the severity of the season, kind and variety of fruits. Besides, the quality of the produce is also affected adversely due to lack of cold storage facilities and the chances for damages to the fruits, the grower capacity to hold stock for better prices during off-season considerably reduced. These facts compelled the growers to dispose off their production in the shortest possible time. This situation naturally leads to slum condition in the market prices and thereby the growers do not get good price. Hence they cannot gain sufficiently from the market facilities. If cold storages facilities are extended to especially in the potential areas particularly at the block level in highly producing areas and at Tehsil level in other areas, then it may prolong the marketing season and may also prove beneficial to the growers. 


\section{Inadequate Credit Facilities}

Credit facilities are very important for the fruit growers, which are inadequate for growers to tide over the period between the time the fruit is harvested and sold. This has resulted in reducing the capability of small growers to hold the fruit for some time through the facilities of cold storage. They sell their products to the middle-men and other such persons, because these agencies finance the growers, when they need such assistance. The growers are morally obliged to dispose of their produce to the middlemen knowing fully well that the return for their commodities is very low. The malpractice which is being regularly perpetuated by the intermediaries, however be abolished or at least their influence can be checked to a large extent if credit facilities on nominal rates are extended to the needy growers, so that they can utilize the facilities of cold storage wherever available.

\section{Lack of Proper Market Information}

Fruit growers in Jammu and Kashmir are also not fully aware of markets prices, because they happen to be located at distances far away from the orchards. Regular visit to big markets like Delhi may solve the problem, to a great extent but it may involve huge expenditure which the poor growers cannot afford to bear. In such situations, they have to accept the rate quoted by the commission agents or intermediaries. Experience show that the information given by commission agents is invariably incorrect as their main purpose is to extract maximum benefits, from the growers through biased information. In view of this, it is desirable that an intensive survey by the government agencies must be conducted of all the big cities, including big rural centres with a view to find out new market centres and also possible diversification of trade.

\section{Problems of Occupation of Gardens by Security Forces}

Fruits growers in Jammu and Kashmir are also facing the problem of occupancy of fruits garden by security forces. Some of the fruits gardens which are located on the hill tops are occupied by the security forces for their camps, which are considered as one of the emerging problem to the fruit growers today. They often don't visit to their garden due to insecurity. Women are also not able to visit their gardens which are occupied by security forces.

Off all the necessary measures to improve the marketing norms, Fruit grower co-operative marketing societies, seem to be the best solution. This will surely minimize the role of preharvest contractors and other intermediaries.

\section{References}

[1]. Prasher, R.S., Nadda, A.L. and Thakur, K.S. (2000). An Economic Analysis of Post Harvest Loses of Apple in Himachal Pradesh, Indian Journal of Agricultural marketing (Special), pp.80-85.

[2]. Yee, W.L, and Goughnour, R. (2006). New Host Records for the Apple Maggot, Rhagoletis Pomonella (Diptera: Tephritidae) in Washington State, Pan-Pacific Entomologist, pp.54-60.

[3]. Jones, V.P, et.al. (1989). Phenology of Apple Maggot (Diptera: Tephritidae) Associated with Cherry and Hawthorn in Utah, Journal of Economic Entomology, pp.788-92.

[4]. Nath, Pushkar. (1933). Diseases of Kashmir Apple, Proceedings of $20^{\text {th }}$ Indian Science Congress, Kolkata, India.

[5]. Kabu, K.L., and Parimoo, M.M. (1972). Boron Deficiency Warrants Attention of Kashmir Orchardists, Horticulture, Vol.3, No.1-3, pp.24-28.

[6]. Girdhari, L., Siddappa, G.S and Tondon, G.L. (1967). Preservation of fruits and Vegetables, Indian Council of Agricultural Research, New Delhi.

[7]. Dahiya, P.S. and Saraswat, S.P. (2000). Marketing of Apples in Himachal Pradesh- Price Spreads, Problems and Strategies, Journal for Applied Horticulture, Society for Advancement of Horticulture, Central Potato Research Institute, Shimla Himachal Pradesh, India, pp.58-61.

[8]. Misra, A.K., (2001). Powdery Mildew- A Serious Disease of Mango, Journal for Applied Horticulture, Society for Advancement of Horticulture, Central Institute for Subtropical Horticulture, Rehmankhera, Kakori, Lucknow, India, pp.63-68.

[9]. Ahlawat, Y.S. (1987). Association of Mycoplasma like Bodies with Citrus Rubberywood Disease, Abstract Presented in the 3rd Regional Workshop on Mycoplasma, p.12.

[10]. Ahlawat, Y.S., Chenulu, V.V. Chakraborthy, N.K. and Vishwanath, S.M. (1984). Occurrence of Impeiteratura Disease of Citrus in India, Current Science, Vol. 53, pp.384-85.

[11]. Ahlawat, Y.S., Chenulu, V.V. Vishwanath S.M. and Pandey K.K. (1985). Studies on a Mosaic Disease of Citrus in India, Current Science, 54, pp.873-74.

[12]. Ahlawat, Y.S. and Sardar, K.K. (1976). A Note on the Lemon Crinkling Leaf Virus in India, Indian Journal of Horticulture, No.33, pp.168-69.

[13]. Byadgi, A.S. and Ahlawat, Y.S. (1995). A New Virus Ring Spot Disease of Citrus in India, Indian Journal of Agricultural Science, No. 65, pp.763-71.

[14]. Chenulu, V.V. and Ahlawat, Y.S. (1993). Virus and Mycoplasma Diseases of Fruit Crops in India, Indian Council of Agricultural Research, New Delhi, India.

[15]. Mali, V.R., Chaudhary, K.G. and Rane, S.D. (1976). Vein Enation Virus Disease in India, Indian Phytopath, Vol.29, pp.43-45.

[16]. Mali, V.R., Chaudhury, K.G. and Rane, S.D. (1976). b. Leaf curl. Virus Disease of Citrus in India, Science and Cultivation, Vol.42, pp.25-27.

[17]. Murthi, V.D. and Reddy, G.S. (1975). Mosaica a Transmissible Disorder of Sweet Oranges, Indian Phytopath, No. 28, pp.398-99.

[18]. Singh, S.J. (1996). In Advances in Diseases on Fruit Crops in India, Kalyani Publishers, Ludhiana, pp.47-92. 
[19]. Neal, J.C. (1889). The Root Disease Nematode of Peach, Orange and Plants in Florida due to the work of Anguillula, Bull. U.S. Bureau of Ent. No.20, p31.

[20]. Siddiqui, M.R. (1964). Studies on Nematode Root Rot of Citrus in Uttar Pradesh, India Proc. Zoological Society (Kolkata), No.17 pp.67-75.

[21]. De, K. and Pandey, Y.D. (1988). Bionomics and Some Behavior Aspects of Mango Fruit Weevil, Sternochetus gravis (F.). Entomo, No.13, pp.17-24.

[22]. Mathur, A.C. and Tondon, P.L. (1974) Litchi Mite Can Be Controlled, Indian Horticulture, No.19, pp.11-12.

[23]. Srivastava, R.P. and Tandon, P.L. (1980). New records of Parasites and Predators of Important Insect Pests of Mango, Entomon, No. 5(3), pp.243-44.

[24]. Srivastava, R.P. and Tandon, P.L. (1981). Bioagents of Insect Pests of Mango in India, Proceedings of Horticultural Seminar, Directorate of Horticulture, Government of U.P, Lucknow.

[25]. Tandon, P.L. (1991). Problems And Prospects of Insect Pest Management in Fruit Trees, In Trends in Agricultural Pest management, Commonwealth Publishers, New Delhi.

[26]. Chowdhuri, H. (1936). Diseases of Citrus in Punjab, Indian Journal of Agricultural Research, No.6, pp.72-109

[27]. Grimm, G.R. and Whidden, R. (1966). Preventing Infection from the Foot Rot Fungus, Proc. Florida State Horticultural Society, No.79, pp.73-75

[28]. Pathak, V.N. (1980). Diseases of Fruit Crops, Oxford \& IBM Publishing Co., New Delhi, p.309.

[29]. Ram, B. and Naidu, R. (1978). Evaluation of Some Fungicides for the Control of Powdery Mildew, Pesticides, No.12 (7), pp.28-30.

[30]. EH, Beers et.al eds. (1993) Orchard Pest Management, Good Fruit Grower, Yakima, WA

[31]. Hiremath, B.N and Vishwa, Ballabh. (2000). Integrating Small Farmers with Market Problem and Prospects, Institute of Rural Management, Anand Gujarat.

[32]. Abrol, D.P. (1993). Insects Pollination and Crop Production in Jammu and kashmir, SKUAST, Regional Agricultural Station, R.S Pura, Current science, Vol. 65, No.p.10. 